JOURNAL OF SCIENTIFIC PERSPECTIVES

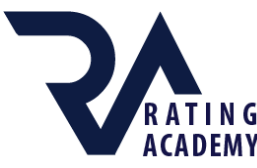

E-ISSN: 2587-3008

April 2018, Vol:2, Issue: 2

JSP

http://ratingacademy.com.tr/journals/index.php/jsp/

\title{
RESEARCH OF COST EFFECT OF OPENNESS AND DECK MATERIAL IN SUSPENSION BRIDGES
}

Ahmed Ali Abdulqader FARHAD

Kirkuk University, Iraq

Ali KÖKEN*

Faculty Of Engineering Department of Civil Engineering Program of Building, Konya, Turkey, Email: akoken@selcuk.edu.tr

\begin{tabular}{|c|c|}
\hline ARTICLE INFO & ABSTRACT \\
\hline $\begin{array}{l}\text { Article History: } \\
\text { Received: } 27 \text { March } 2018 \\
\text { Accepted: } 26 \text { April } 2018\end{array}$ & $\begin{array}{l}\text { Recently, the following rapid development of the national economy and the } \\
\text { advancement of communication and transportation, the construction of Long- } \\
\text { Span Suspension Bridges have been increasing gradually. Long-Span Suspension } \\
\text { Bridges are greatly preferred by engineering designers rather than other bridges }\end{array}$ \\
\hline $\begin{array}{l}\text { Keywords: Suspension } \\
\text { bridge, Bridge, Bridge Cost, } \\
\text { Bridge Elements, AASHTO } \\
\text { LRFD, CSI Bridge program. }\end{array}$ & $\begin{array}{l}\text { equipped with construction supporting systems, not only for economic reasons, } \\
\text { but also Long-Span suspension bridges are in the possession of advanced } \\
\text { construction techniques when we deal with long distances, for Long-Span } \\
\text { suspension bridges acquire supporting constructions features rigged with main } \\
\text { cables and ropes. Long-Span suspension bridges are bridge constructions } \\
\text { included with cable systems and under strong nonlinear factor effects, which the }\end{array}$ \\
\hline DOI: $10.26900 / j s p .2018 .11$ & $\begin{array}{l}\text { more the suspension increases, the more the bridges construction lightens, and the } \\
\text { more the flexibility grows. There is a lot differences shown in the cost of the } \\
\text { Suspension bridges according to different opening. The effect of the deck material } \\
\text { is like the effect of the openness. The cost of the suspension bridge in the world is } \\
\text { to be discussed too, so the cost is to investigate the effect of opening the } \\
\text { drawbridge. The cost of suspension bridges in the world is very controversial, so } \\
\text { investigating the financial effect of openness and deck material on suspension } \\
\text { bridges is required. In this study, a three-dimensional model of the main cable, } \\
\text { suspension rope, deck and tower elements of suspension bridge system by using } \\
\text { CSI Bridge Program was constructed and numerical analysis was carried out. The } \\
\text { standards used in analysis and design are used the AASHTO LRFD standard, } \\
\text { which is common in the world. Suspension bridges of 250, 500, 750, 1000, 1500, } \\
2000 \text { meters were analyzed and designed in different deck material and openings. } \\
\text { The material and cost of the suspension bridges have been investigated. The costs } \\
\text { according to the openness and deck material of Suspension bridges have been } \\
\text { shown by the obtained results. }\end{array}$ \\
\hline
\end{tabular}

\section{INTRODUCTION}

All the discoveries made by mankind are to sustain. It was first discovered places to live, found something to eat, especially invented new tools for hunting and has constructed buildings for shelter. Bridges are one of these examples. The first bridges were built from the throne over the years in $5000 \mathrm{BC}$ to cross barriers or openings.

These structures, which seem to be easy at first, have become more complicated with time due to the increase of openings and the multiple openings by adding columns together. 
The complexity and the size of the structure have brought social importance to be the forefront. Thus, bridges are not only structural but also as a social object are to be the forefront (Akca, 2009).

As countries and societies evolve, the importance of transportation is increasing and the need for transportation structures (bridges, viaducts, etc.) increases parallel to this situation, and these buildings become prestige structures. One of these prestige constructions built in developed and developing countries is the large span Suspension bridges (Boduroğlu, 2007).

Suspension bridges are the oldest steel bridge type, not the new inventions developed by the technique. In Eastern Asia, South America and Ecuador Africa, suspension bridges have been used in ancient times. The first suspension bridge was built by the Chinese using chain and ropes. There are only 100-year past of the suspension bridges used today. With the development of steel cables and the use as carrier system material, great developments have been made in suspension bridges (Günaydın, 2011).

The suspension bridge is a type of bridge that has been thought of since the early ages for pass through large openings. In the general, more than $100 \mathrm{~m}$ openings are passing, and the construction of suspension bridge instead of concrete and steel construction lattice systems is a more suitable solution (Cengizoğlu, 2006). Suspension bridges can easily be built in large openings with the help of development in engineering and construction technologies (Boduroğlu, 2007).

The suspension bridge is composed of the cables and ropes hanging deck carrying the main load. Since the cable and suspension elements are playful, additional rigidity elements are used to rig the bridge. Additional required rigidity is generally provided by exploiting the bridge deck.

The most important problem in suspension bridges is to eliminate the swing. Since this swing can not be completely removed, the remedy for lowering it to the smallest possible level has always been explored. Today, due to the developing technology possibilities, rigidity is ensured by using bridge decks. To reduce the effects of wind, bridge cross-section aerodynamically shape is formed (Cengizoğlu, 2006).

The main elements of carrying and supporting such bridges are deck system, $\mathrm{H}$ tower with suspension cables etc.; Among those factors, The $\mathrm{H}$ tower with suspension cables supports the total weight of bridges, even it supports the weight of vehicles, winds, and other heavy loads.

The working principle of the suspension bridges has been tried to be explained simply. Suspension bridges have two carrier edge feet, two main carrier cables and anchorages masses connected by main carrier cables. The road we said the deck where the vehicles pass is suspended to two main carrier cables with the help of cables called suspension rods and usually in vertical position (Karataş et al., 2000).

Suspension bridges, before being built tower and anchoring systems were built. After building the tower, the main cable is pulled. After the main cable is pulled, the hanger ropes are connected to the main cable and by means of a crane the pavers start gradually from the middle of the main opening to an equal number of mounting to the two ends (Günaydın, 2011).

\section{MATERIAL AND METHODS}

In this study; the analysis and design were carried out with the CSI Bridge program to investigate the cost effect of openness and deck material in suspension bridges commonly used in the passage of large openings. The AASHTO LRFD Specification, which is widely used in the world, was used in the analysis and design in the study (AASHTO, 2012). 
The bridge openings covered in the study are as follows:
a. 250 meter
b. 500 meter
c. 750 meter
d. 1000 meter
e. 1500 meter
f. 2000 meter

The deck systems of the bridge considered in the study are as follows:
a. Concrete Deck Suspension Bridges
b. Steel Deck Suspension Bridges

\subsection{Suspension Bridge}

Bridge is one of the most important engineering structures that have made life easier since the existence of human beings. Since ancient times, bridges, streams, deep valleys, even continents have been making it easier for people to cross. In the past, bridges were made of masonry and wooden materials that could carry small, narrow spans and light loads; today, these bridges are replaced by reinforced concrete and steel bridges. For this purpose, nowadays, reinforced concrete and steel bridges are being built which can carry, large spans and heavy loads.

Suspended bridges are more economical engineering structures than similar ones in terms of passing large openings and using the areas under the bridge comfortably. Suspension bridges are also important in terms of engineering. Considering the high construction costs of these bridges and the logistical importance of the regions in which they are located, it turns out that the structural behavior of such engineering structures should be well defined. Because getting damage to this type of bridges, means that the loss of life and property as well as the lack of transport links (Atabey, 2011).

\subsubsection{Basic Characteristics of Suspended Bridges}

Suspension bridges are structures used to pass large openings of 550 meters. The edge openings are on the floor. If the distance between the floor and the edge opening is small, the edge openings can be formed by a single hanging clearance built on the floors sitting on the floor, which is a more economical solution from the material point of view. When it is desired to pass large openings, medium and edge openings can be hanged. In the case where the passage of much larger openings is the case, they are designed as four or more openings. Suspension bridge consists of different behavioral elements such as main cable, decks, towers, hanging bar, tower top saddle and anchor blocks (Mubuli, 2016).

\subsubsection{Elements of Suspension Bridges}

Suspension bridge consists of main elements such as tower, anchor, cable, hangers and decks. On the bases that constitute support for the towers, when it is necessary to construct in the water, they become important because they are expensive and difficult. So multi - span suspension bridge construction is not avoided unless it is necessary.

\subsubsection{Towers}

Suspension bridge towers are reinforced concrete structures built higher than the surface of the deck. Towers are subject to unequal tensile forces by the main cables of openings in the center and edge. However, to prevent overturning of the towers, care is taken to ensure that the horizontal components of the tensile forces are equal. The towers stand box girders forming generally are hollow. Elevators are provided in the towers to provide access to the support 
saddles for road level and maintenance. Each tower is composed of two feet and these feet are connected to each other by horizontal or diagonal beams (Atabey, 2011).

\subsubsection{Cables}

The main cables take the load on the deck with hanger ropes and transfer it to the floor through the tower and anchor blocks. The main cables are usually made of galvanized steel wire with a diameter of $5 \mathrm{~mm}$ and strength of $160-180 \mathrm{~kg} / \mathrm{mm} 2$. After the main cables are formed, they are primed and painted after they are covered with soft galvanized wire so that they can be protected from external influences (Atabey, 2011).

\subsubsection{Hanger ropes}

The hanger ropes transfer the load on the deck to the main cable. The hanger ropes transfer the load on the deck to the main cable. Each hanger consists of three elements, hangerdeck connection, hanger-cable connection and hanger itself. The hangers are formed from steel bars, may be in the twisted wire ropes or parallel wire ropes. In modern suspension bridges, the most commonly used type of hanger is those with twisted wire ropes (Atabey, 2011).

\subsubsection{Deck}

Decks are longitudinally structures that emit and carry moving car loads. The conveyor system of the deck to be used by the vehicles is made of reinforced concrete or steel with box section. As material, concrete has high pressure resistance and low tensile stress. The use of concrete is appropriate when the deck of the suspension bridges is reduced by tensile stress cables. Lifting is carried out by means of an itinerant crane arranged between the main cables. The concrete deck is happen large cross section and heavy, while the steel deck is happen smaller cross section and lighter. Concrete and steel decks are widely used in suspension bridges (Atmaca, 2012).
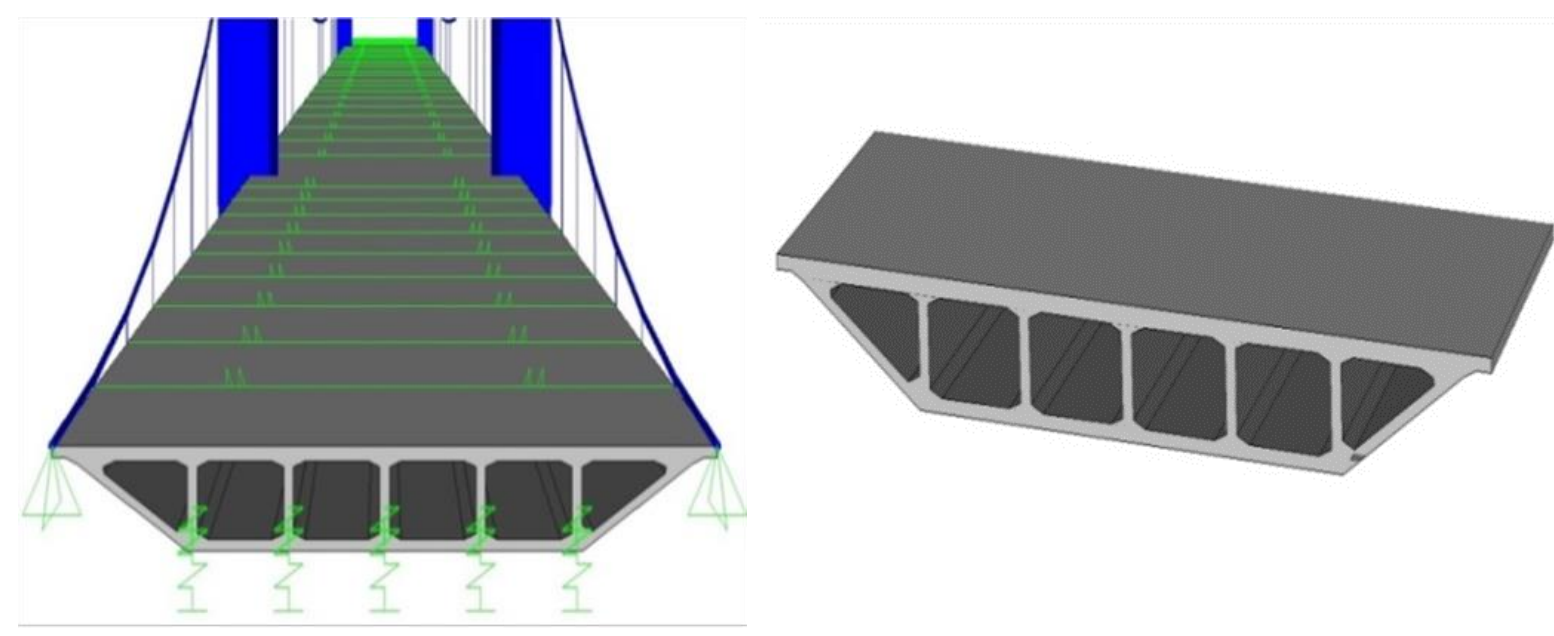

Figure 1 . Concrete Deck Used in Computer Model. 


\subsection{AASHTO LRFD Standards}

AASHTO-LRFD allows for the design of bridges with force-based linear methods for certain bridges, considering the nonlinear, supra-elastic behavior of bridges in terms of material. This regulation replaced the AASHTO directive in the United States. The existing AASHTO regulation is based on the load factor method (LFD), AASHTO-LRFD adopted the design according to the load and strength factor (LRFD). Compared to these two regulations, safe design ranging from 3.2 to 4 times according to changing bridges openings in the LRFD regulations and safe design ranging from 1.5 to 4.5 times in AASHTO regulations (Uluğ, 2008).

\subsection{Computer Model of Bridge}

The computer model of the build was done using the CSI Bridge program. The bridge carrier system is modeled in 3 dimensions as main cable, hanger ropes, deck and tower and it is evaluated by solution under vertical loads and earthquake loads. In the description of the truck load on the deck, the moving load module of the CSI Bridge program is used. The weights and masses of the carrier elements are automatically calculated by the program. If the weight and mass of the non-bearing elements are (asphalt, railing, etc.), the prepared model is also entered (Uluğ, 2008).

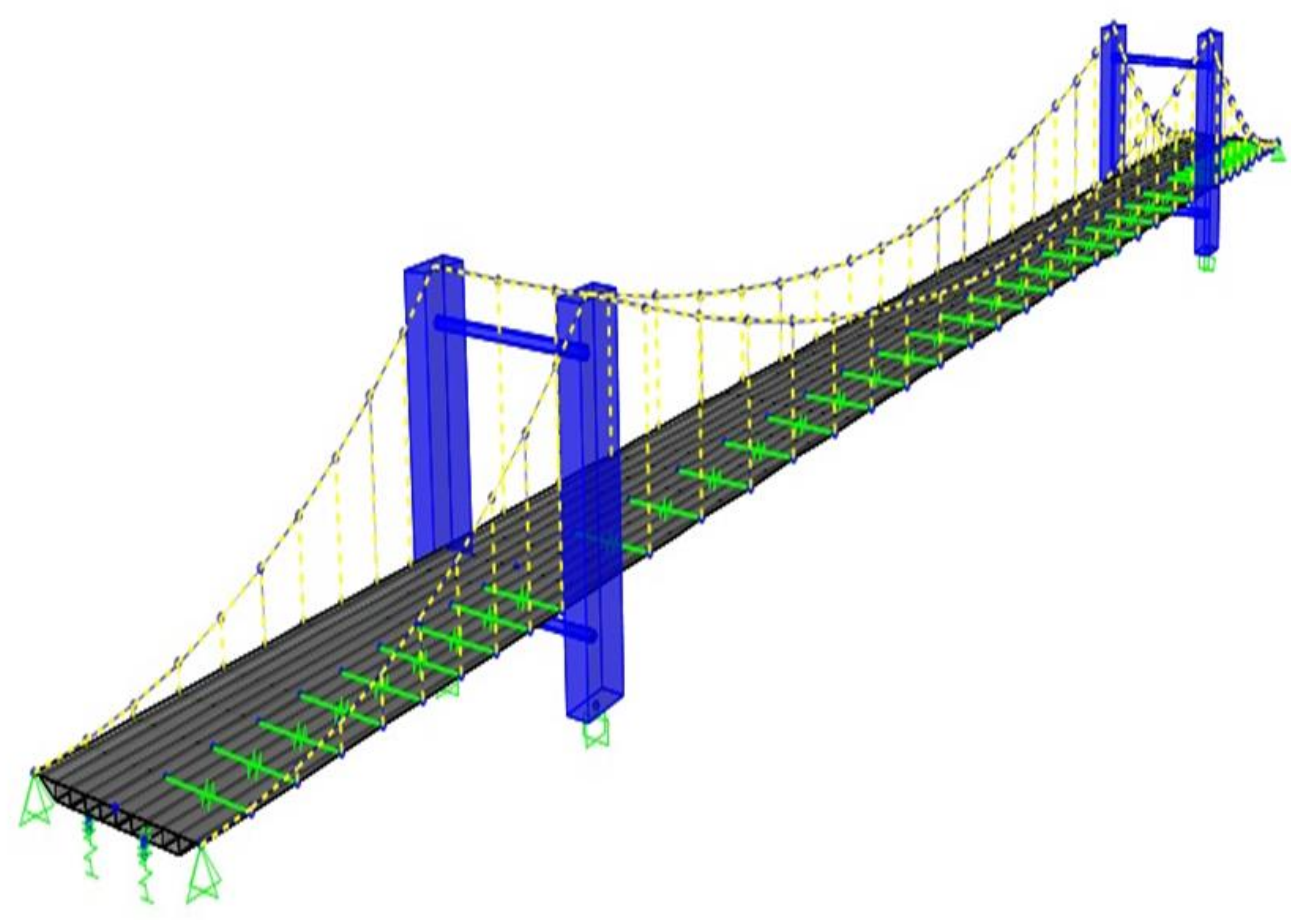

Figure 2. Computer Model of Steel Deck Suspension Bridge.

\section{OBTAINED RESULTS}

In this study, six different openings suspension bridge analysis were carried out. Suspension bridge at 250, 500, 750, 1000, 1500, 2000 meter openings were modeled using CSI Bridge computer program, also analysis and design was carried out. Sample images of the results of the analysis and design are given in the figures below. 

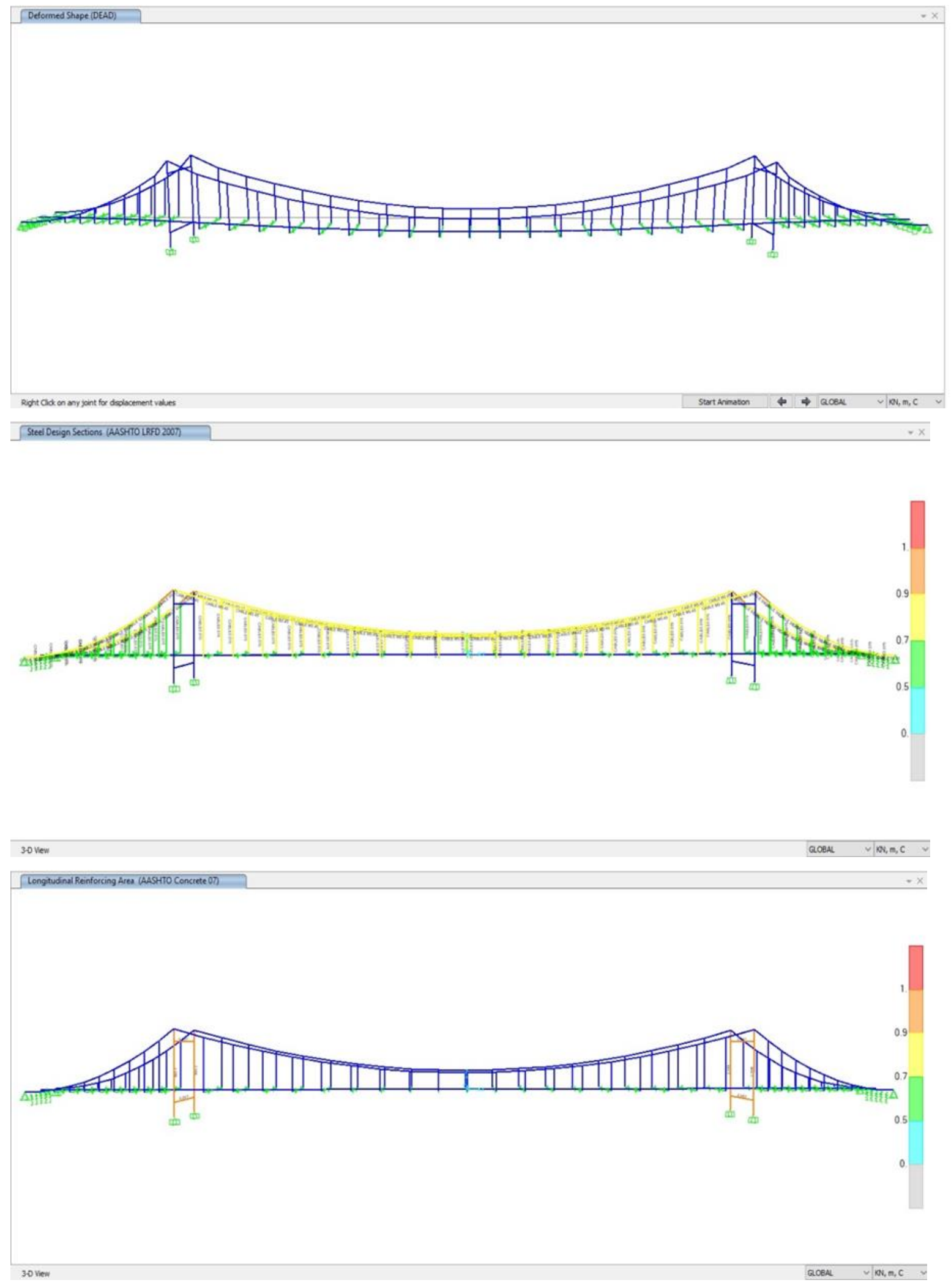

Figure 3- 5. Concrete Section Design 
At the end of the design performed, weight and cost calculations of bridges were made. Cost calculations have been denominated in US dollars and using actual prices.

Table 1. Material price list

\begin{tabular}{|c|c|}
\hline Element & Unit Price \\
\hline Cable & $1500 \quad \$ /$ ton \\
\hline Concrete & $40 \quad \$ / \mathrm{m}^{3}$ \\
\hline Reinforcement steel & $650 \quad \$ /$ ton \\
\hline Profile steel & $650 \quad \$ /$ ton \\
\hline
\end{tabular}

After getting the calculations results from the analyses and designs by using CSI bridge program. For the following tables, considering that deck materials that used in this study is concrete and steel, for clear view purposes, the results have been classified as tables for better way to understand it and to explain it according to deck materials and costs for multi bridge spans.

Table 2. Amount of material for the concrete deck suspension bridges

\begin{tabular}{|c|c|c|c|c|}
\hline \multirow{2}{*}{$\begin{array}{c}\text { Name of the } \\
\text { Bridge }\end{array}$} & \multicolumn{4}{|c|}{ Material Weight (Ton) } \\
\cline { 2 - 5 } & $\begin{array}{c}\text { Total } \\
\text { Concrete } \\
\text { (Ton) }\end{array}$ & $\begin{array}{c}\text { Total } \\
\text { Concrete } \\
\left(\mathrm{m}^{3}\right)\end{array}$ & $\begin{array}{c}\text { Total } \\
\text { Reinforcement } \\
\text { Steel (Ton) }\end{array}$ & $\begin{array}{c}\text { Cable } \\
\text { Steel(Ton) }\end{array}$ \\
\hline ASM250-BE & 37.042 & 15.434 & 3.246 & 765 \\
\hline ASM500-BE & 133.085 & 55.452 & 13.861 & 2.700 \\
\hline ASM750-BE & 287.464 & 119.777 & 27.302 & 5.823 \\
\hline ASM1000-BE & 529.347 & 220.561 & 58.030 & 10.582 \\
\hline ASM1500-BE & 1.255 .556 & 523.148 & 137.949 & 22.991 \\
\hline ASM2000-BE & 2.450 .059 & 1.020 .858 & 252.782 & 40.344 \\
\hline
\end{tabular}

Table 3. Material Price and Bridge Price for the concrete deck suspension bridges

\begin{tabular}{|c|c|c|c|c|c|}
\hline \multirow{2}{*}{$\begin{array}{c}\text { Name of the } \\
\text { Bridge }\end{array}$} & $\begin{array}{c}\text { Total } \\
\text { Concrete } \\
\text { Price }\end{array}$ & $\begin{array}{c}\text { Reinforcement } \\
\text { Steel } \\
\text { Price }\end{array}$ & $\begin{array}{c}\text { Cable } \\
\text { Steel } \\
\text { Price }\end{array}$ & $\begin{array}{c}\text { Total Price } \\
(\$)\end{array}$ & $\begin{array}{c}\text { Mridge } \\
\text { Unit Cost } \\
(\$ / \text { meter })\end{array}$ \\
\cline { 2 - 4 }$(\$)$ & $(\$)$ & $(\$)$ & 3.874 .518 & 15.498 \\
\hline ASM250-BE & 617.365 & 2.110 .164 & 1.146 .988 & 30.555 \\
\hline ASM500-BE & 2.218 .084 & 9.009 .332 & 4.050 .330 & 15.277 .746 & 30.55 \\
\hline ASM750-BE & 4.791 .069 & 17.746 .616 & 8734349 & 31.272 .034 & 41.696 \\
\hline ASM1000-BE & 8.822 .455 & 37.719 .704 & 15.873 .271 & 62.415 .430 & 62.415 \\
\hline ASM1500-BE & 20.925 .934 & 89.667 .063 & 34.486 .346 & 145.079 .343 & 96.720 \\
\hline ASM2000-BE & 40.834 .310 & 164.308 .390 & 60.516 .045 & 265.658 .745 & 132.829 \\
\hline
\end{tabular}


Table 4. Amount of material for the steel deck suspension bridges

\begin{tabular}{|c|c|c|c|c|c|}
\hline \multirow{2}{*}{$\begin{array}{c}\text { Name of the } \\
\text { Bridge }\end{array}$} & \multicolumn{5}{|c|}{ Material Weight (Ton) } \\
\cline { 2 - 6 } & $\begin{array}{c}\text { Total } \\
\text { Concrete } \\
(\text { Ton) }\end{array}$ & $\begin{array}{c}\text { Total } \\
\text { Concrete } \\
\left(\mathrm{m}^{3}\right)\end{array}$ & $\begin{array}{c}\text { Total } \\
\text { Reinforcement } \\
\text { Steel (Ton) }\end{array}$ & $\begin{array}{c}\text { Profile } \\
\text { steel } \\
\text { (Ton) }\end{array}$ & $\begin{array}{c}\text { Cable } \\
\text { Steel } \\
(\text { Ton) }\end{array}$ \\
\hline ASM250-CE & 10.172 & 4.239 & 997 & 5.260 & 300 \\
\hline ASM500-CE & 47.324 & 19.718 & 5.395 & 10.520 & 1.056 \\
\hline ASM750-CE & 120.556 & 50.232 & 13.728 & 15.779 & 2.253 \\
\hline ASM1000-CE & 244.364 & 101.818 & 26.020 & 21.039 & 4.133 \\
\hline ASM1500-CE & 751.816 & 313.257 & 80.094 & 52.893 & 12.394 \\
\hline ASM2000-CE & 1.748 .434 & 728.514 & 184.868 & 102.365 & 27.684 \\
\hline
\end{tabular}

Table 5. Material Price and Bridge Price for the steel deck suspension bridges

\begin{tabular}{|c|c|c|c|c|c|c|}
\hline \multirow{3}{*}{$\begin{array}{c}\text { Name of the } \\
\text { Bridge }\end{array}$} & \multicolumn{6}{|c|}{ Material Price (\$) } \\
\hline & $\begin{array}{c}\text { Total } \\
\text { Concrete } \\
\text { Price }\end{array}$ & $\begin{array}{c}\text { Reinforcement } \\
\text { Steel } \\
\text { Price }\end{array}$ & $\begin{array}{c}\text { Cable Steel } \\
\text { Price }\end{array}$ & $\begin{array}{c}\text { Profile } \\
\text { Steel Price }\end{array}$ & \multirow[t]{2}{*}{$\begin{array}{c}\text { Total Price } \\
\qquad(\$)\end{array}$} & \multirow{2}{*}{$\begin{array}{l}\text { Bridge } \\
\text { Unit Cost } \\
\text { (\$/meter) }\end{array}$} \\
\hline & $(\$)$ & $(\$)$ & $(\$)$ & $(\$)$ & & \\
\hline ASM250-CE & 169.541 & 648.006 & 449.678 & 3.418 .853 & 4.686 .079 & 18.744 \\
\hline ASM500-CE & 788.730 & 3.506 .706 & 1.583 .743 & 6.837 .706 & 12.716 .885 & 25.434 \\
\hline ASM750-CE & 2.009 .267 & 8.923 .462 & 3.378 .969 & 10.256 .559 & 24.568 .257 & 32.758 \\
\hline ASM1000-CE & 4.072 .733 & 16.912 .980 & 6.199 .843 & 13.675 .413 & 40.860 .969 & 40.861 \\
\hline ASM1500-CE & 12.530 .268 & 52.061 .257 & 18.591 .076 & 34.380 .300 & 117.562 .901 & 78.375 \\
\hline ASM2000-CE & 29.140 .575 & 120.164 .342 & 41.526 .227 & 66.537 .503 & 257.368 .647 & 128.684 \\
\hline
\end{tabular}

The following graphics have been used to view the results comparison between the bridge systems of concrete deck and steel deck. These graphics shows the huge differences in the amount of these materials which affect the costs of the bridges in general.

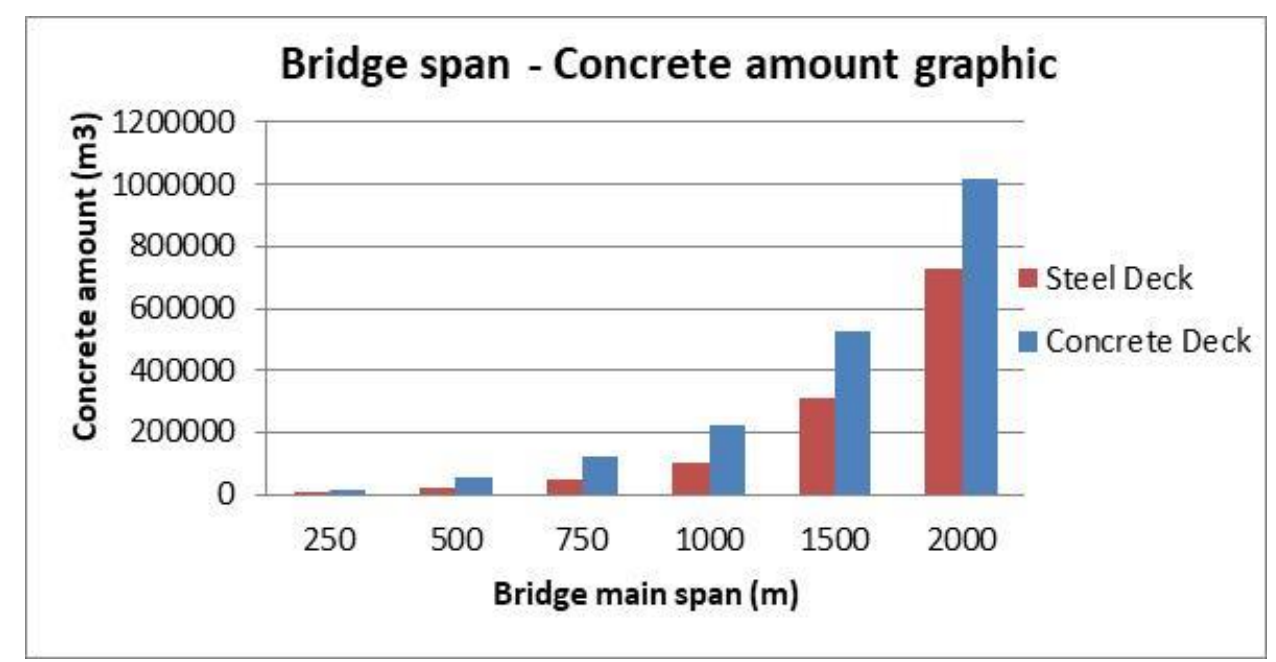

Figure 6. Bridge span - Concrete amount graphic 


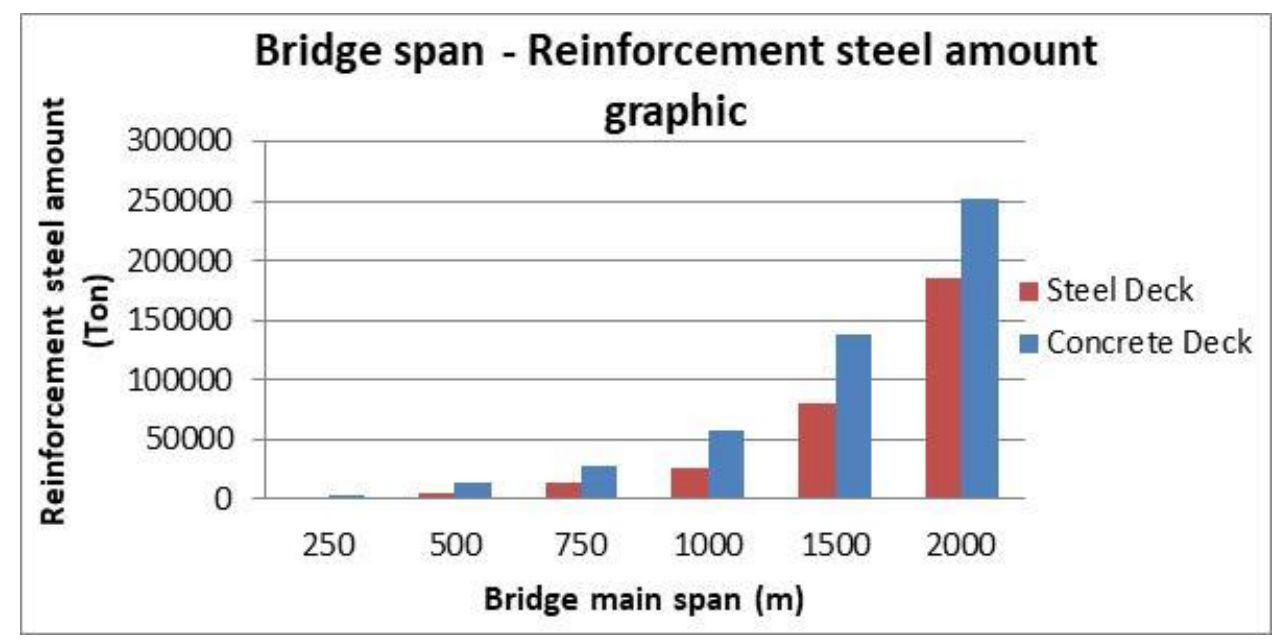

Figure 7. Bridge span - Reinforcement steel amount graphic

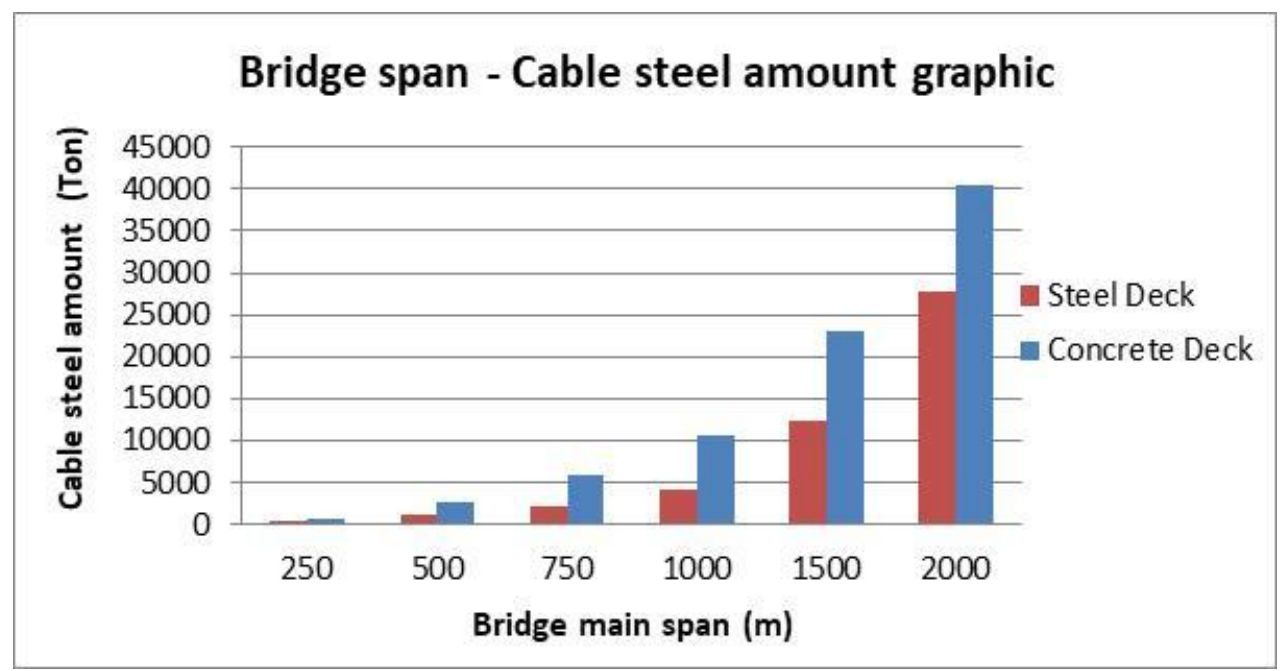

Figure 8. Bridge span - Cable steel amount graphic

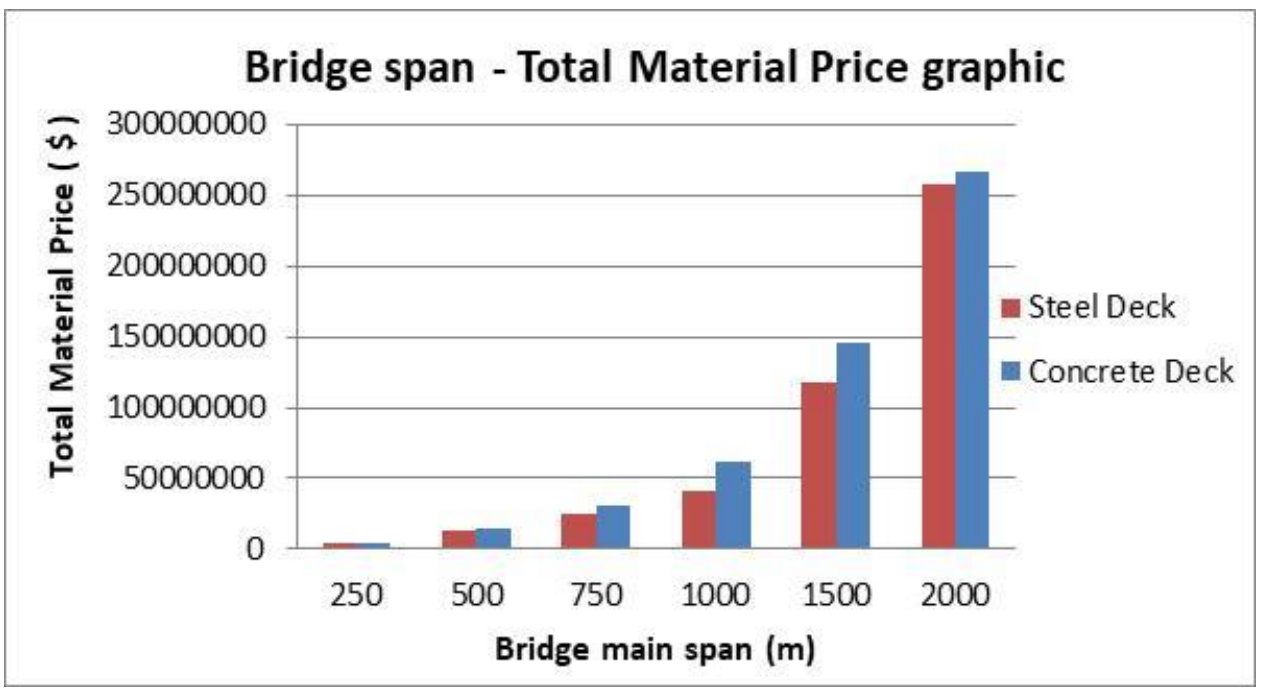

Figure 9. Bridge span - Total Material Price graphic 


\section{CONCLUSIONS AND RECOMMENDATIONS}

At the end of the analysis and cost calculations made, the following results have been achieved.

- Total cost of construction is increasing considerably, is as the case in the span of bridge. However, the increase in the unit construction cost is much higher than the prevailing value of openness. The unit cost is increasing at the higher degree, not proportionally to the passed openness. Namely; despite the 8-fold increase in openness for a 2000-meter clearance with a 250-meter clearance the increase in total construction cost is approximately 69 times for reinforced concrete deck bridges and 55 times for steel deck bridges.

- While the reinforced concrete deck suspension bridge gives economic results for the opening of 250 meters, after this openness, steel deck suspension bridges are becoming more economical.

- With the new studies to be done, similar cost analysis can be done for different bridge building systems and the economics of different bridge building systems can be investigated according to the openings. 


\section{REFERENCES}

AASHTO, 2012, AASHTO LRFD 2012 Bridge Design Specifications 6th Edition, US, American Association of State Highway and Transportation Officials.

AKCA, H. A., 2009, Modeling Of Steel Arch Bridge With Finite Element Modeling Program, Master Thesis, Gazi University.

ATABEY, N. A., 2011, Static and Dynamic Analyses of Fiber Reinforced Polymer Suspension Bridges, Master Thesis, Karadeniz Technical University.

ATMACA, B., 2012, Construction Stage Analysis of Three Dimensional Cable-Stayed Bridge, Master Thesis, Karadeniz Technical University.

BODUROĞLU, M. K., 2007, A Numerical Study on Seismic Performance Evaluation of Cable Stayed Bridges by Nonlinear Time History Analysis, Master Thesis, Istanbul Technical University.

CENGİZOĞLU, H., 2006, The Comparison of the Strength of Undamaged Suspension Bridge with Current Situation, One of the Rods Broke Off, Master Thesis, Istanbul University.

GÜNAYDIN, M., 2011, Determination of Structural Behavior of Suspension Bridges Considering Construction Stage and Time Dependent Material Properties, Master Thesis, Karadeniz Technical University.

KARATAŞ, H., KIYMAZ, G. and COŞKUN, E., 2000, Asma Köprüler [online], Istanbul kültür university, http://web.iku.edu.tr/ ecoskun/ASMA\%20KÖPRÜLER.doc: [Date Accessed: 4 February 2018].

MUBULI A., 2016, Determining the Structural Behavior of Fatih Sultan Mehmet Suspension Bridge under Earthquake Loads and Vehicle Loads, Master Thesis, Yildiz Technical University.

ULUĞ, N. I., 2008, Structural Design of Bridge with Prestressed Girder and Seismic Performance Assessment, Master Thesis, Istanbul Technical University. 
FARHAD and KÖKEN / Research of Cost Effect of Openness and Deck Material in Suspension Bridges 